\title{
REVIEW
}

\section{Role of tau in Alzheimer's dementia and other neurodegenerative diseases}

\author{
Amita Quadros $^{1,2}$, Ophelia Inez Weeks ${ }^{2}$, Ghania Ait-Ghezala $^{1,2}$ \\ ${ }^{1}$ Roskamp Institute, Sarasota, Florida, U.S.A. \\ ${ }^{2}$ Department of Biological Sciences, Florida International University, Miami, Florida, U.S.A.
}

Received $1^{\text {st }}$ November 2006.

Revised $19^{\text {th }}$ December 2006.

Published online $12^{\text {th }}$ February 2007.

\begin{abstract}
Summary
Alzheimer's disease (AD) is defined histopathologically by beta-amyloid (A $\beta$ ) senile plaques and neurofibrillary tangles (NFTs) composed of hyperphosphorylated tau. The question as to which of these lesions takes precedence in AD pathology has long been an issue of debate. The amyloid cascade hypothesis, currently the predominant hypothesis, considers $A \beta$ peptide to be responsible for the major neurodegeneration observed in $\mathrm{AD}$ while the cytoskeleton hypothesis states that tau hyperphosphorylation and subsequent aggregation may be central to the neurodegeneration observed in AD. This review focuses on tau mutations, phosphorylation sites, tau isoforms and the neurohistopathology of $\mathrm{AD}$, and three other tauopathies to demonstrate that disease progression and neuronal loss in AD correlate also with pathological tau and not just amyloid deposition. Although tau is at the center of all these neurodegenerative diseases, there exist differences in morphology, isoforms, phosphorylation sites and mutations in each of these tauopathies. The tauopathies discussed in this review are $\mathrm{AD}$, progressive supranuclear palsy, Pick's disease, and frontotemporal dementia and Parkinsonism linked to chromosome 17.
\end{abstract}

Keywords: tauopathies - progressive supranuclear palsy - Pick's disease - frontotemporal dementia Parkinsonism

\section{INTRODUCTION}

Weingarten and colleagues first discovered a microtubule-associated protein tau (MAPT) in 1975 (Weingarten et al. 1975). Tau in the central nervous system (CNS) is found predominantly in axons of neurons, to a smaller extent in cell bodies

Amita Quadros, Roskamp Institute, 2040 Whitfield Avenue, Sarasota, FL-34243, U.S.A.

Daquadros@rfdn.org

용 941-752-2949

具 941-752-2948 and to an even lesser extent in dendrites (Binder et al. 1985, Papasozomenos and Binder 1987). Tau is also present in glial cells although generally under pathological conditions (Berry et al. 2001). The major function of tau in the CNS is in the stabilization of microtubules in neurons and tau might be involved in the establishment and maintenance of neuronal polarity. The C-terminus of tau binds to axonal microtubules while the $\mathrm{N}$ terminus binds to neural plasma membrane components suggesting that tau functions as a linker protein between both. Besides this, tau is also involved in various signal transduction pathways where tau binds with non-receptor src family tyrosine kinases and influences neurite 
growth and the motility of microtubules in response to extracellular signals (Buee et al. 2000). However, all of these functions of tau are dependent on its ability to be phosphorylated at site-specific epitopes.

The tau gene located on human chromosome $17 \mathrm{q} 21$ in the human genome, contains 16 exons with the major tau isoform being encoded by 11 exons (Goedert et al. 1989, Spillantini and Goedert 1998). Alternative pre-mRNA splicing of exons 2 , 3 and 10 in the single tau gene results in the formation of six different isoforms in the adult human brain (Buee et al. 2000). These isoforms ranging from 352-441 amino acids are responsible for the modulation of tau function and are characterized by the presence of three (3R tau) or four (4R tau) tandem repeats of 31-32 amino acids located in the carboxy terminal end which is also the microtubule binding domain of tau (Goedert et al. 1989). These tandem repeats of $3 R$ and $4 R$ are encoded by exons 9-12 (exon 10 inclusion results in the generation of $4 \mathrm{R}$ tau while its exclusion generates $3 \mathrm{R}$ tau). In the adult human brain the ratio of $3 R$ tau to $4 R$ tau is approximately 1 and this balance is disrupted in the case of tau mutations associated with exon 10 (Goedert and Jakes 2005, D'Souza and Schellenberg 2005). In the N-terminal region there is a presence/absence of a 29 or 58 amino acid insert (exon 2 alone or exons 2 and 3 together), respectively. This $\mathrm{N}$ terminal insert is the major factor responsible for variability in the six isoforms (Buee et al. 2000). In the foetal human brain, exons 2, 3 and 10 are excluded and a single isoform is produced comprised of 316 amino acids (D'Souza and Schellenberg 2005). Foetal tau in the CNS is more highly phosphorylated than tau in the adult brain.

Various kinases and phosphatases are involved in the regulation of tau phosphorylation that occurs at a number of serine, threonine and proline residues (Butler and Shelanski 1986, Ferrer et al. 2005). Tau hyperphosphorylation is at the crux of most tauopathies since hyperphosphorylation dissociates tau from microtubules, destabilizes them and forms paired helical filaments (PHF) in vitro (Lindwall and Cole 1984, Alonso et al. 1994). Tau phosphorylation is regulated by an exquisite equilibrium between kinase and phosphatase activities. An imbalance of these two enzymatic processes can result in abnormal hyperphosphorylation of tau and the generation of PHF. Mutations in the tau gene and tau hyperphosphorylation have been observed in many neurodegenerative diseases as well as in senescent brains. Neurodegenerative diseases of note include Pick's disease, AD, frontotemporal dementia with Parkinsonism linked to chromosome 17 (FTDP17), progressive supranuclear palsy (PSP), corticobasal degeneration, Niemann Pick's disease, etc. These diseases are all referred to as tauopathies since they all share a common pathology which is aggregated tau. This review focuses on four disorders, since each differs substantially in their tau pathology, especially with respect to AD.

\section{ALZHEIMER'S DISEASE (AD)}

AD is named after Dr. Alois Alzheimer, a German physician who observed changes in the brain tissue of a woman in 1906 (Moller and Graber 1998). To date, the cause and progression of sporadic $\mathrm{AD}$ have not been fully elucidated. $\mathrm{AD}$ is neuropathologically characterized by the presence of extracellular amyloid deposits and intracellular NFTs composed of hyperphosphorylated tau. NFTs are preferentially observed in hippocampal cells and the entorhinal cortex. In addition, many cortical and sub-cortical areas such as the amygdala and dorsal raphe nucleus are affected also by NFT formation. Symptoms of the disease include memory loss followed by aphasia, agnosia, apraxia and behavioral disturbances. The disease generally affects people over 65 years of age.

The autosomal-dominant inherited forms of early-onset Alzheimer's disease are caused by mutations in the genes encoding the amyloid precursor protein (APP), presenilin 1 (PS-1) on chromosome 14, and presenilin 2 (PS-2) on chromosome 1 (Buee et al. 2000). A polymorphism in the apolipoprotein $\mathrm{E}$ gene (the $E 4$ allele) is also a genetic risk factor associated with late-onset $\mathrm{AD}$ (Wilhelmus et al. 2005). Studies supporting the amyloid cascade hypothesis suggest that amyloid is upstream of tau and could be a significant factor in hyperphosphorylating tau, resulting in the formation of neurofibrillary tangles followed by neurodegeneration (Hardy and Selkoe 2002). This theory is supported by various transgenic mouse models of $\mathrm{AD}$ that have been studied in the recent past to monitor effects of amyloid beta peptide (A $\beta$ and tau on cognition and memory deficits, in an attempt to mimic human AD neuropathology of plaques and tangles (Gotz et al. 2001). In the triple transgenic mice with $A P P, P S-1$ and $P 301 L$ mutations, intracerebral injection with anti-A $\beta$ antibodies decreased tau pathology in younger mice further supporting the claim that $A \beta$ could be upstream of tau (Oddo et al. 2004). However, other studies in transgenic mice have demonstrated $M A P T$ mutations in combination with $A P P$ mutations show more neurodegeneration as opposed to APP mutations alone (Lewis et al. 2001).

Immunoblotting of $\mathrm{AD}$ tau proteins isolated from aggregated PHF's reveals the presence of a major tau triplet (tau 55, 64 and $69 \mathrm{kd}$ ) and an additional minor 72-74 $\mathrm{kd}$ component in the case of AD thereby differentiating it from the other 
tauopathies (Mailliot et al. 2000). Also via immunoassay techniques, pathologic tau with distinctive morphology and specificity to AD can be detected. Tau hyperphosphorylation in $\mathrm{AD}$ results in the reduced ability of tau to bind to microtubules. Hyperphosphorylation of tau in $\mathrm{AD}$ generates differences that can be visualized by phosphorylation-dependent antibodies that include AT100, AP422, 988, TG3 and PHF-27 (Augustinack et al. 2002a).

In $\mathrm{AD}$, tau is hyperphosphorylated at 30 specific amino acid sequences throughout its 441 amino acids (Gong et al. 2005). In vitro studies suggest that increases in $A \beta$ production may potentiate tau phosphorylation by activation of kinases such as glycogen synthase kinase-3 (GSK3) (Alvarez et al. 1999). Phosphorylated tau protein at T231 is seen in the postmortem brain tissue of patients with $\mathrm{AD}$ and can be detected in cerebrospinal fluid (Buerger et al. 2002). Additional studies indicate that increased activation of the stress related kinases JNK and p38 occurs very early in the disease and might be involved in the intraneuronal protein phosphorylation/ dephosphorylation imbalance that leads to neurofibrillary degeneration in $\mathrm{AD}$ (Reynolds et al. 2000, Pei et al. 2001). It is noteworthy that p35/Cdk5 kinase complex can phosphorylate human tau at seven sites S195, S202, T205, T231, S235, S396 and S404 (Paudel et al. 1993). Also, in vitro studies show increased levels of $\mathrm{p} 25$, an activator of cdk5 that phosphorylates tau at S199, S202, and T205 (Augustinack et al. 2002b). And, immunoblotting studies using anti-pS208 and antipS210 show that tau-tubulin kinase phosphorylates S208 and S210 in PHF-tau (Tomizawa et al. 2001).

The phosphorylation sites and immunohistochemistry of tau in AD differentiate it from the other tauopathies. In addition, there are no known mutations in tau that are associated with AD as opposed to the other tauopathies (Gotz et al. 2006). Although Gerstmann-Straussler-Scheinker disease (GSS), a prion disease has amyloid plaques as a result of pathological prions they differ in tau pathology from AD morphologically and also with respect to differences in tau isoforms and by immunohistochemistry. In contrast to AD, GSS shows low levels of the major tau triplet (tau 55, 64 and $69 \mathrm{kd}$ ) (Mailliot et al. 2000).

\section{PROGRESSIVE SUPRANUCLEAR PALSY (PSP)}

PSP, the second most frequent cause of degenerative Parkinsonism was identified by Clifford Richardson, Steele and Olszewski in 1964 (Steele et al. 1964). Neuropathologically, PSP is characterized by abundant neurofibrillary tangles that are primarily localized to subcortical regions and are found in both neurons and glia. Clinical phenotypes of PSP are similar to Parkinson's disease and include unsteady gait, stiff movements and mild dementia due to a selective loss of caudal intralaminar nuclei that result in the loss of dopaminergic neurons in the substantia nigra (Henderson et al. 2000). Other symptoms include blurred vision, downward gaze palsy, followed by depression, sleeplessness, memory loss, dysphagia and dysarthria. Men are more prone to this disease than women and the age of onset varies from the early forties to late eighties.

The etiology of this disease is not fully understood but data implicate polymorphisms in the tau gene as a risk factor. Conrad et al. (1997) first identified a dinucleotide polymorphism involving a TG repeat in intron 9. The TG repeat of 11 dinucleotides is termed the $A O$ allele, while the $A 1, A 2, A 3$ and $A 4$ alleles represent 12,13, 14 and 15 dinucleotide repeats, respectively. Subsequent studies have shown that this polymorphism is inherited as part of two extended haplotypes (H1 and $\mathrm{H} 2$ ) that cover the entire tau gene (Baker et al. 1999). The $A 0, A 1$ and $A 2$ alleles are present in haplotype $\mathrm{H} 1$ while $A 3$ and $A 4$ are part of haplotype $\mathrm{H} 2$. However, these polymorphisms are not specific to PSP because $A O$ allele and $\mathrm{H} 1$ haplotype are also implicated in corticobasal degeneration (Houlden et al. 2001). Mutations in the tau gene associated with neuropathology typical of PSP include a silent mutation S305S in exon 10, a R5L in exon 1, and G303V mutation in exon 10 (Stanford et al. 2000, Poorkaj et al. 2002, Ros et al. 2005a) (Table 1). All of the above mutations result in the predominant tau isoform being $4 \mathrm{R}$ tau. The deletion of asparagine at codon 296 (del296) of the tau gene causes atypical PSP in patients homozygous for this mutation while the heterozygous mutation phenotypically resembles Parkinson's disease (Grover et al. 2002). The S352L homozygous tau gene mutation found in two English siblings showed tau neuropathology different from FTDP-17 cases and functional studies showed reduced microtubule assembly and increased aggregation of tau. Both siblings carried the H1/H1 haplotype associated with PSP (Nicholl et al. 2003). In addition to mutations in the tau gene, studies have also shown linkage of PSP to a new locus $1 q 31.1$ in chromosome 1 (Ros et al. 2005b).

Pathological and biochemical studies in PSP brains have shown a predominance of hyperphosphorylated aggregated $4 \mathrm{R}$ tau isoforms (Litvan and Hutton 1998). Tau pathology in the postmortem PSP brain may include neuropil threads, neuritic plaques, tufted astrocytes and glial inclusions, as well as microglia and globose tangles (Morris et al. 2002). Ultrastructural analyses have revealed differences in AD and PSP pathology. Tau 
morphology in AD is PHFs whereas the tau filaments are straight in PSP (Spillantini and Goedert 1998, Morris et al. 2002). In addition, electrophoretic profiles of aggregated tau proteins in PSP differ from that of $\mathrm{AD}$. In $\mathrm{AD}$ all six isoforms of tau are phosphorylated and the aggregated tau, as detected by immunoblotting appears as a major tau triplet (tau 55, 64 and $69 \mathrm{kd}$ ) while in PSP only the $4 \mathrm{R}$ isoforms are phosphorylated and appear as a major tau doublet (tau 55 and $64 \mathrm{kd}$ ) (Mailliot et al. 2000).

The kinases that may cause hyperphosphorylation of tau in PSP are phosphop38 MAPK, and the stress kinases SAPK/JNK-P which are upregulated in neurons, astrocytes and oligodendroglia displaying aggregated tau (Ferrer et al. 2001). Another kinase that is implicated in abnormal phosphorylation of tau in PSP is casein kinase 1 delta (Schwab et al. 2000).

\section{PICK'S DISEASE}

Arnold Pick first described Pick's disease in 1892 (Karenberg 2001). Pick's disease differs from AD in several aspects. It is marked by rounded microscopic structures called Pick's bodies rather than the plaques and tangles of AD. Pick's disease is characterized by frontotemporal lobar atrophy, gliosis and ballooned neurons. The first symptoms associated with this disease are personality changes, poor social judgement, difficulty with language and poor attention span. The onset is usually at 40 years of age and is less common after 60 years of age.

Pick's disease is also referred to as one of the fronto-temporal dementias (FTDs) caused by mutations in the tau gene in exons 9, 12, 11 and 13 (Murrell et al. 1999, Yen et al. 1999, Rizzini et al. 2000, Pickering-Brown et al. 2000, Neumann et al. 2001, Rosso et al. 2002, Hogg et al. 2003, Bronner et al. 2005) (Table 1). All mutations associated with Pick's disease and identified in table 1 show a reduced microtubule assembly of tau. Functional analysis of tau with G389R and K257T mutations have demonstrated increased susceptibility of tau to calpain I digestion (a feature probably related to the formation of a Pick's disease type of histology) in addition to reduced microtubule assembly of tau (Pickering-Brown et al. 2000). Besides mutations in the tau gene, a novel mutation $\mathrm{G} 183 \mathrm{~V}$ in the presenilin-1 (PS-1) gene affects the splice signal at the junction of the sixth exon and intron resulting in clinical manifestations similar to Pick-type tauopathy, in the absence of extracellular betaamyloid deposits (Dermaut et al. 2004). Subsequent studies showed that a mutation in PS-1, M146L which accounts for most cases of familial AD can also cause Pick's disease (Halliday et al. 2005). PS-
1 mutations are known to enhance gammasecretase activity resulting in an increase in $\mathrm{A} \beta 42$ (Haass and De Strooper 1999). However, PS-1 mutations in addition to increasing $\mathrm{A} \beta 42$ also increase the production of total tau proteins (Shepherd et al. 2004). The mechanism of action of M146L mutation is hypothesized to predispose the person to Pick's disease, or AD, or both, by affecting multiple intracellular pathways involved with tau phosphorylation, resulting in $3 \mathrm{R}$ isoforms and amyloid metabolism (Halliday et al. 2005).

Histopathologically, Pick's bodies are intraneuronal inclusions of tau, and only phosphorylated 3R-tau isoforms aggregate into filaments. They are characterized as a major tau doublet (tau 55 and $64 \mathrm{kd}$ ) (Mailliot et al. 2000). However, studies have also revealed $4 \mathrm{R}$ aggregated tau isoforms in patients with sporadic Pick's disease, although the 3R isoforms are more predominant (Zhukareva et al. 2002). Interestingly, analysis of dephosphorylated tau from the brain of a patient with the G389R mutation revealed a prominent tau band with $4 \mathrm{R}$ isoforms and no amino terminal inserts (Murrell et al. 1999). Ultrastructurally, Pick's bodies consist of both random coiled and straight filaments. Further, aggregated tau proteins in Pick's disease are not detected by the monoclonal antibody $12 \mathrm{E} 8$ that binds to phosphorylated Ser262/356 residues, as is the case with other neurodegenerative diseases. This lack of 12E8 immunoreactivity suggests either a kinase inhibition in neurons that degenerate in Pick's disease or an absence of the related kinases (Probst et al. 1996). Furthermore, the active stress kinase p38 has been shown to enhance abnormal tau phosphorylation in Pick's disease (Puig et al. 2004). The other kinases implicated in Pick's disease are similar to those involved in PSP.

\section{FRONTOTEMPORAL DEMENTIA AND PARKINSONISM LINKED TO CHROMOSOME 17 (FTDP-17)}

The name frontotemporal dementia was first proposed by the Lund and Manchester group in 1994 (Mori 2004). Wilhelmsen and colleagues renamed FTD as FTDP-17 after observing clinical and pathological features of frontotemporal dementia in patients with genetic defects in chromosome 17q21-22 (Buee et al. 2000). FTDP17 is characterized by behavioural, cognitive and motor disturbances that are caused by lesions in the frontotemporal regions of the brain. The pattern of inheritance in FTDP-17 is autosomal dominant with an early age of onset between 45-65 years of age. Pathological changes in the brain include frontotemporal atrophy with neuronal loss, gray and white matter gliosis and superficial cortical spongiform. 
Table 1. Tau mutations on chromosome 17

\begin{tabular}{|c|c|c|c|c|}
\hline Mutations & $\begin{array}{l}\text { Exon } \\
\text { location }\end{array}$ & Pathogenic effects of Tau mutations & $\begin{array}{l}\text { Disease } \\
\text { Pathology }\end{array}$ & Literature cited \\
\hline $\mathrm{R} 5 \mathrm{H}$ & 1 & $\begin{array}{l}\text { Increased aggregation of tau } \\
\text { protein, reduced MT assembly and } \\
\text { all six isoforms affected }\end{array}$ & AD-like & $\begin{array}{l}\text { Hayashi et al. 2002, D’Souza and } \\
\text { Schellenberg } 2005\end{array}$ \\
\hline $\mathrm{R} 5 \mathrm{~L}$ & 1 & $\begin{array}{l}\text { Increased aggregation of tau } \\
\text { protein, reduced MT assembly and } \\
\text { all six tau isoforms affected }\end{array}$ & PSP & Poorkaj et al. 2002 \\
\hline K257T & 9 & $\begin{array}{l}\text { Increased aggregation of tau } \\
\text { protein, reduced MT assembly and } \\
\text { all six tau isoforms affected }\end{array}$ & Pick's disease & Rizzini et al. 2000 \\
\hline $\mathrm{I} 260 \mathrm{~V}$ & 9 & $\begin{array}{l}\text { Increased aggregation of tau } \\
\text { protein, reduced MT assembly and } \\
\text { all six tau isoforms affected }\end{array}$ & FTDP-17 & Brandt et al. 2005 \\
\hline L266V & 9 & $\begin{array}{l}\text { Increased aggregation of tau } \\
\text { protein, reduced MT binding and all } \\
\text { six tau isoforms affected, increases } \\
\text { splicing of exon } 10\end{array}$ & Pick's disease & $\begin{array}{l}\text { Hogg et al. 2003, D'Souza and } \\
\text { Schellenberg } 2005\end{array}$ \\
\hline G272V & 9 & $\begin{array}{l}\text { Increased aggregation of tau } \\
\text { protein, reduced MT binding, } \\
\text { all six tau isoforms affected }\end{array}$ & $\begin{array}{l}\text { Pick's } \\
\text { disease, } \\
\text { FTDP-17 }\end{array}$ & $\begin{array}{l}\text { Bronner et al. 2005, Hutton et al. } \\
\text { 1998, Spillantini and Goedert } 1998\end{array}$ \\
\hline $\mathrm{N} 279 \mathrm{~K}$ & 10 & $\begin{array}{l}\text { Increase splicing of exon } 10 \\
\text { changing 4R:3R ratio }\end{array}$ & FTDP-17 & $\begin{array}{l}\text { Sergeant et al. 2005, D'Souza and } \\
\text { Schellenberg } 2005\end{array}$ \\
\hline $\operatorname{delK} 280$ & 10 & $\begin{array}{l}\text { Increased aggregation of tau } \\
\text { protein, decreases splicing of exon } \\
\text { 10, reduced MT assembly }\end{array}$ & FTDP-17 & Brandt et al. 2005 \\
\hline L284L & 10 & $\begin{array}{l}\text { Increase splicing of exon } 10 \\
\text { changing 4R:3R ratio }\end{array}$ & AD-like & D'Souza and Schellenberg 2005 \\
\hline Delta N296 & 10 & $\begin{array}{l}\text { Reduces microtubule assembly of } \\
\text { tau and increases tau aggregation }\end{array}$ & $\begin{array}{l}\text { PSP \& } \\
\text { FTDP-17 }\end{array}$ & $\begin{array}{l}\text { Grover et al. 2002, Yoshida et al. } \\
2002\end{array}$ \\
\hline $\mathrm{N} 296 \mathrm{H}$ & 10 & $\begin{array}{l}\text { Increases splicing of exon } 10, \\
\text { increases tau aggregation and } \\
\text { reduces tau promoted tubulin } \\
\text { polymerization }\end{array}$ & FTDP-17 & Grover et al. 2002 \\
\hline $\mathrm{N} 296 \mathrm{~N}$ & 10 & $\begin{array}{l}\text { Increases splicing of exon } 10 \\
\text { thereby increasing ratio of } 4 \mathrm{R} / 3 \mathrm{R} \\
\text { tau }\end{array}$ & FTD & Grover et al. 2002 \\
\hline P301L & 10 & $\begin{array}{l}\text { Increased aggregation of tau } \\
\text { protein, does not affect splicing of } \\
\text { exon } 10 \text {, reduced MT binding, } 4 \mathrm{R} \\
\text { tau isoforms }\end{array}$ & FTDP-17 & Hutton et al. 1998 \\
\hline P301S & 10 & $\begin{array}{l}\text { Increased aggregation of tau } \\
\text { protein, does not affect splicing of } \\
\text { exon } 10 \text {, reduced MT binding }\end{array}$ & FTDP-17 & Sergeant et al. 2005 \\
\hline G303V & 10 & $\begin{array}{ll}\text { Increases splicing of exon } 10 \\
\text { increasing } & 4 \mathrm{R} / 3 \mathrm{R} \text { ratio }\end{array}$ & PSP & Ros et al. $2005 \mathrm{a}$ \\
\hline $\mathrm{S} 305 \mathrm{~N}$ & 10 & $\begin{array}{lll}\text { Increase } & \text { microtubule } & \text { assembly, } \\
\text { increases } & \text { splicing of exon } 10 \\
\text { increasing } & 4 \mathrm{R} / 3 \mathrm{R} \text { ratio }\end{array}$ & Pick's disease & $\begin{array}{l}\text { Sergeant et al. 2005, D'Souza and } \\
\text { Schellenberg } 2005\end{array}$ \\
\hline S305S & 10 & $\begin{array}{l}\text { Increase splicing of exon } 10 \\
\text { increasing } 4 \mathrm{R} / 3 \mathrm{R} \text { ratio }\end{array}$ & PSP & Stanford et al. 2000 \\
\hline L315R & 11 & Reduced MT assembly & $\begin{array}{l}\text { Pick's/ } \\
\text { FTDP-17 }\end{array}$ & Brandt et al. 2005 \\
\hline K317M & 11 & & FTDP-17 & Zarranz et al. 2005 \\
\hline S320F & 11 & Reduced MT assembly & $\begin{array}{l}\text { Pick's disease } \\
\text { pathology }\end{array}$ & Rosso et al. 2002, Brandt et al. 2005 \\
\hline Q336R & 12 & $\begin{array}{l}\text { Increase microtubule assembly, } \\
\text { Increased aggregation of tau protein }\end{array}$ & $\begin{array}{l}\text { Pick's disease } \\
\text { pathology }\end{array}$ & Pickering-Brown et al. 2004 \\
\hline V337M & 12 & $\begin{array}{l}\text { Increased aggregation of tau } \\
\text { protein, reduced MT binding }\end{array}$ & AD-like & Poorkaj et al. 1998 \\
\hline
\end{tabular}




\begin{tabular}{|c|c|c|c|c|}
\hline E342V & 12 & $\begin{array}{l}\text { Increased exon } 10 \text { splicing, no } \\
\text { effect on MT assembly }\end{array}$ & $\begin{array}{l}\text { FTDP-17/ } \\
\text { Pick's }\end{array}$ & Lippa et al. 2000, Brandt et al. 2005 \\
\hline S352L & 12 & $\begin{array}{l}\text { Reduced MT assembly and } \\
\text { increased aggregation of tau protein }\end{array}$ & PSP & Nicholl et al. 2003 \\
\hline K369I & 12 & Reduced MT assembly & $\begin{array}{l}\text { Pick's disease } \\
\text { pathology }\end{array}$ & Neumann et al. 2001 \\
\hline G389R & 13 & Reduced MT assembly & Pick's / FTD. & Murrell et al. 1999 \\
\hline R406W & 13 & $\begin{array}{l}\text { Increased aggregation of tau } \\
\text { protein, reduced MT assembly }\end{array}$ & PSP & Hutton et al. 1998 \\
\hline $\mathrm{T} 427 \mathrm{M}$ & 13 & & FTDP-17 & Giaccone et al. 2005 \\
\hline
\end{tabular}

Most of the known mutations causing FTDP17 occur in the C-terminal end of tau and affect mainly exons 9-12 that encode the microtubule binding repeats. The different tau mutations give rise to different pathological characteristics depending on their location. Missense mutations outside exon 10 result in the formation of straight neuronal filaments in all six isoforms. These filaments resemble the PHFs observed in AD. In contrast, missense or splice mutations that directly affect exon 10 result in both neuronal and glial tau pathology with filaments consisting predominantly of 4R tau isoforms (van Slegtenhorst et al. 2000).

Tau mutations causing FTDP-17 either alter the ratio of 4R:3R tau through faulty splicing of exon 10 or directly impair the binding of tau to microtubules and its subsequent aggregation properties. FTDP-17 mutations affecting exon 10 are presented in Table 1 . The intronic mutations in the 5' splice site of exon10 are E10+3, E10+11, $\mathrm{E} 10+12, \quad \mathrm{E} 10+13, \quad \mathrm{E} 10+14, \quad \mathrm{E} 10+16, \quad \mathrm{E} 10$ $+33, \mathrm{E} 10+19$, E10 +29 (Hutton et al. 1998, van Slegtenhorst et al. 2000, Mack et al. 2001, Morris et al. 2003, Sergeant et al. 2005). Exon 10 and intronic mutations following exon 10 affect the cellular functioning and biochemical expression of tau by changing the normal $1: 1$ ratio of $3 \mathrm{R}: 4 \mathrm{R}$ isoforms. Most of the intronic mutations increase splicing of exon 10 except E10+19 and E10+29 (which decrease the splicing of exon 10) and result in the predominant tau isoform being $4 \mathrm{R}$. Mutations affecting exon 10 cause ribbon twisted filaments of mostly $4 \mathrm{R}$ tau that do not bind to microtubules. Mutations outside of exon 10 result in PHF and straight filaments generally affecting all 6 isoforms that do not bind to microtubules (Sergeant et al. 2005). Most of these mutations alter the ability of tau to interact with microtubules thereby increasing the likelihood that tau will assemble into filaments (Brandt et al. 2005). However, other mutations like delN296, N296N and $\mathrm{N} 296 \mathrm{H}$ reduce the ability of tau to promote assembly of microtubes, without having a significant effect on tau filament formation (Yoshida et al. 2002).
Other mutations involved with FTDP-17 include a $\mathrm{R} 5 \mathrm{H}$ mutation in exon 1 which reduces microtubule assembly and promotes formation of fibrils in vitro, a T427M mutation in exon 13 identified in an Italian patient with a family history of FTD, and the E342V mutation in exon 12 which preferentially increases 4R tau (Hayashi et al. 2002, Giaccone et al. 2005, Lippa et al. 2000 respectively). The Q336R mutation in exon 12 of the tau gene increases microtubule assembly of tau in vitro while an adjacent mutation V337M decreases microtubule assembly of tau (PickeringBrown et al. 2004). The tau pathology associated with these two different mutations although adjacent to each other is also different. The former mutation results in Pick-type tau histology while the latter has NFTs similar to AD, like tau pathology (Poorkaj et al. 1998, Pickering-Brown et al. 2004). Another mutation implicated in FTDP-17 is the $\mathrm{K} 317 \mathrm{M}$ mutation located in exon 11 of the $M A P T$ gene. Biochemical analysis of brain homogenates revealed two bands of phospho-tau at 64 and $68 \mathrm{kd}$ (Zarranz et al. 2005). However, there have been many cases of familial FTDP-17 with no detectable mutations in the tau gene. Recent studies have shown that these cases of familial FTDP-17 are caused by mutations in the progranulin gene situated just next to the tau gene (Baker et al. 2006, Cruts et al. 2006).

Studies on FTDP-17 mutations expressed in differentiated neuronal cells reveal decreased phosphorylation of pathologically relevant S202/T205 sites, but phosphorylation at the S396/S404 site is moderately decreased for all mutant isoforms (Furukawa et al. 2003). Other studies suggest that mutations in tau that decrease its microtubule-binding capacity augment calcium influx by depolymerizing microtubules and activating adenyl cyclase and protein kinase A (Buee-Scherrer et al. 2002). Transgenic mouse models with the different mutations of tau have been developed to study the effects of tau pathology on cognition and memory. Some of these mouse models have been successful in mimicking the molecular and cellular features of the human 
disease in terms of hyperphosphorylation and filament formation (Goedert and Jakes 2005).

\section{DISCUSSION}

Tau, a microtubule-associated protein, is abnormally hyperphosphorylated in senescent tissue and in a number of neurodegenerative diseases collectively referred to as tauopathies. There is no known cure to date for each of the tauopathies discussed in this review. All available therapies provide only symptomatic relief. The key challenge facing scientists in the area of neurodegenerative diseases is the need to develop effective therapeutic agents that could lead to a cure for these diseases.

Tau is a substrate for various protein kinases in vitro, namely, the $\mathrm{Ca}++/$ Calmodulin dependent protein kinase II, Casein kinase II, GSK3, the MAPK, also known as ERK, cdk5 and the microtubule affinity regulating kinase (MARK). The stress activated protein kinases
SAPK3/p38gamma and SAPK4/p38delta also cause abnormal hyperphosphorylation of tau (Buee-Scherrer et al. 2002). Each kinase phosphorylates different residues that are proline or non-proline specific. GSK3 phosphorylates S199 but not detectably S202 or T205. The MAPKs may not be strictly proline specific. p38 phosphorylates the nonproline sites S185, T245, S305, and S356. The MAPKs and GSK3 are important tau kinases that may be involved in the pathogenic hyperphosphorylation of tau in AD (Paudel et al. 1993). Phosphorylated tau is dephosphorylated by numerous protein phosphatases in vitro. Phosphatase 1, phosphatase 2A and the $\mathrm{Ca}++$ /calmodulin-dependent phosphatase, phosphatase 2B all have been shown to dephosphorylate tau (Gong et al. 1994a, Gong et al. 1994b). Dephosphorylation of tau by these phosphatases increases the ability of tau to bind to microtubules and also promotes microtubule assembly.

In vitro models used to verify these results are PC12 cells and SH-SY5Y neuroblastoma cells.

Table 2. Summary of the tauopathies

\begin{tabular}{|c|c|c|c|}
\hline Disease & Tau repeats & $\begin{array}{l}\text { Age of onset } \\
\text { (years) }\end{array}$ & Literature cited \\
\hline Pick's & 3 repeat & $40-60$ & $\begin{array}{l}\text { Pickering-Brown et al. 2004, } \\
\text { Mailliot et al. } 2000\end{array}$ \\
\hline PSP & 4 repeat & Early 40 - late 80 & $\begin{array}{l}\text { Mailliot et al. 2000, } \\
\text { Morris et al. } 2003\end{array}$ \\
\hline $\mathrm{AD}$ & 3 repeat +4 repeat & Over 65 & $\begin{array}{l}\text { Mailliot et al. } 2000 \text {, } \\
\text { Gotz et al. } 2006\end{array}$ \\
\hline FTDP-17 & 3 repeat +4 repeat & $45-65$ & $\begin{array}{l}\text { Mailliot et al. 2000, } \\
\text { Pickering-Brown et al. } 2004\end{array}$ \\
\hline
\end{tabular}

However, it is also important to mention at this stage that tau hyperphosphorylation alone is not the predisposing factor for all these tauopathies. Other factors like oxidative stress, enzyme regulation, cellular vulnerability and genetic mutations also play a major role in the pathogenicity of tauopathies. Although mutations in PS-1 account for the majority of familial cases of $\mathrm{AD}$ and cause an increased production of $\mathrm{A} \beta 42$, little is known about the role of tau in PS-1 AD. There is a 6-fold increase in tau-2-positive plaques in PS-1 cases thereby suggesting that PS-1 mutations increase tau hyperphosphorylation perhaps by increasing $A \beta$, which in turn activates GSK-3 (Shepherd et al. 2004). This theory supports the amyloid cascade hypothesis of amyloid being upstream of tau in AD.
Various transgenic mice have been developed to study the effects of tau mutations and the various kinases and phosphatases on tau, and to monitor the neuropathology in vivo. There has been some success in the latter with the development of transgenic mice expressing wild type tau and mutant tau P301L (Lewis et al. 2000). Other transgenic mouse models have included glial pathology in addition to neuronal pathology (Higuchi et al. 2002). Although transgenic mice with the mutant V337M mutation are said to show behavioral and pathological features similar to AD (Tanemura et al. 2002), they still do not completely simulate or mimic the conditions in the human brain. The triple transgenic mouse (APP, PS-1 and tau) model shows the closest resemblance of $\mathrm{AD}$ pathology in humans with respect to plaques and 
tangles (Oddo et al. 2003). Researchers have also tried to mimic human AD pathology in monkeys with a view to finding suitable therapeutic agents to treat the disease. However, the drawback of this model of AD is the extended time period (around 10 years) necessary for $\mathrm{A} \beta$ deposition in these primates (Ridley et al. 2006). To further investigate the hypothesis that NFTs are responsible for brain dysfunction and neurodegeneration, transgenic mice expressing mutant tau that could be suppressed with doxycycline were created (Santacruz et al. 2005). These mice showed improved memory function after suppression of human mutant tau but did not prevent the accumulation of NFTs. Also, MAPT mutations along with APP mutations cause more neurodegeneration in AD mouse models than APP mutations alone (Lewis et al 2001) and studies from human tissue with AD show that NFTs correlate better with impairment than amyloid (Arriagada et al 1992). Altogether, these results suggest that abnormal tau correlates more with the pathogenesis of $\mathrm{AD}$ than amyloid. And, although transgenic mice have allowed considerable progress in our understanding, they still present limitations for modeling human AD. An overview of the different isoforms of tau in various tauopathies including age of onset is presented in Table 2. Both amyloid and tau hypotheses have their strengths and drawbacks and continued efforts should be made in both areas towards finding a cure for $\mathrm{AD}$ and other tauopathies.

\section{REFERENCES}

Alonso AC, Zaidi T, Grundke-Iqbal I, Iqbal K: Role of abnormally phosphorylated tau in the breakdown of microtubules in Alzheimerdisease. Proc. Natl. Acad. Sci. U.S.A. 91:5562-5566, 1994.

Alvarez G, Munoz-Montano JR, Satrustegui J, Avila J, Bogonez E, Diaz-Nido J: Lithium protects cultured neurons against betaamyloid-induced neurodegeneration. FEBS Lett. 453:260-264, 1999.

Arriagada PV, Growdon JH, Hedley-Whyte ET, Hyman BT: Neurofibrillary tangles but not senile plaques parallel duration and severity of Alzheimer's disease. Neurology 42:631-639, 1992

Augustinack JC, Schneider A, Mandelkow EM Hyman BT: Specific tau phosphorylation sites correlate with severity of neuronal cytopathology in Alzheimer's disease. Acta Neuropathol. 103:26-35, 2002a.

Augustinack JC, Sanders JL, Tsai LH, Hyman BT: Colocalization and fluorescence resonance energy transfer between cdk5 and AT8 suggests a close association in preneurofibrillary tangles and neurofibrillary tangles. J. Neuropathol. Exp. Neurol. 61:557564, 2002b.

Baker M, Litvan I, Houlden H, Adamson J, Dickson D, Perez-Tur J, Hardy J, Lynch T, Bigio E, Hutton M: Association of an extended haplotype in the tau gene with progressive supranuclear palsy. Hum. Mol. Genet. 8:711$715,1999$.

Baker M, Mackenzie IR, Pickering-Brown SM, Gass J, Rademakers R, Lindholm C, Snowden J, Adamson J, Sadovnick AD, Rollinson S, Cannon A, Dwosh E et al.: Mutations in progranulin cause tau-negative frontotemporal dementia linked to chromosome 17. Nature 442:916-919, 2006.

Berry RW, Quinn B, Johnson N, Cochran EJ, Ghoshal N, Binder LI: Pathological glial tau accumulations in neurodegenerative disease: review and case report. Neurochem. Int. 39:469-479, 2001.

Binder LI, Frankfurter A, Rebhun LI: The distribution of tau in the mammalian central nervous system. J. Cell Biol. 101:1371-1378, 1985.

Brandt R, Hundelt M, Shahani N: Tau alteration and neuronal degeneration in tauopathies: mechanisms and models. Biochim. Biophys. Acta 1739:331-354, 2005.

Bronner IF, Ter Meulen BC, Azmani A, Severijnen LA, Willemsen R, Kamphorst W, Ravid R, Heutink P, van Swieten JC: Hereditary Pick's disease with the G272V tau mutation shows predominant three-repeat tau pathology. Brain 128:2645-2653, 2005.

Buee L, Bussiere T, Buee-Scherrer V, Delacourte A, Hof PR: Tau protein isoforms, phosphorylation and role in neurodegenerative disorders. Brain Res. Brain Res. Rev. 33:95130, 2000.

Buee-Scherrer V, Goedert M: Phosphorylation of microtubule-associated protein tau by stressactivated protein kinases in intact cells. FEBS Lett. 515:151-154, 2002.

Buerger K, Zinkowski R, Teipel SJ, Tapiola T, Arai H, Blennow K, Andreasen N, HofmannKiefer K, DeBernardis J, Kerkman D, McCulloch C, Kohnken R et al.: Differential diagnosis of Alzheimer disease with cerebrospinal fluid levels of tau protein phosphorylated at threonine 231. Arch. Neurol. 59:1267-1272, 2002.

Butler M, Shelanski ML: Microheterogeneity of microtubule-associated tau proteins is due to differences in phosphorylation. J. Neurochem. 47:1517-1522, 1986.

Conrad C, Andreadis A, Trojanowski JQ, Dickson DW, Kang D, Chen XH, Wiederholt W, Hansen L, Masliah E, Thal LJ, Katzman R, 
Xia Y, et al.: Genetic evidence for the involvement of tau in progressive supranuclear palsy. Ann. Neurol. 41:277-281, 1997.

Cruts M, Gijselinck I, van der Zee J, Engelborghs S, Wils H, Pirici D, Rademakers R, Vandenberghe R, Dermaut B, Martin JJ, van Duijn C, Peeters K et al.: Null mutations in progranulin cause ubiquitin-positive frontotemporal dementia linked to chromosome 17q21. Nature 442:920-924, 2006.

Dermaut B, Kumar-Singh S, Engelborghs S, Theuns J, Rademakers R, Sacrens J, Pickut BA, Peeters K, van den Broeck M, Vennekens $\mathrm{K}$, Claes S, Cruts $\mathrm{M}$ et al.: A novel presenilin 1 mutation associated with Pick's disease but not beta-amyloid plaques. Ann. Neurol. 55:617626, 2004.

D'Souza I, Schellenberg GD: Regulation of tau isoform expression and dementia. Biochim. Biophys. Acta 1739:104-115, 2005.

Ferrer I, Blanco R, Carmona M, Puig B: Phosphorylated mitogen-activated protein kinase (MAPK/ERK-P), protein kinase of 38 $\mathrm{kDa}(\mathrm{p} 38-\mathrm{P})$, stress-activated protein kinase (SAPK/JNK-P), and calcium/calmodulindependent kinase II (CaM kinase II) are differentially expressed in tau deposits in neurons and glial cells in tauopathies. J. Neural. Transm. 108:1397-1415, 2001.

Ferrer I, Gomez-Isla T, Puig B, Freixes M, Ribe E, Dalfo E, Avila J: Current advances on different kinases involved in tau phosphorylation, and implications in Alzheimer's disease and tauopathies. Curr. Alzheimer Res. 2:3-18, 2005.

Furukawa K, Wang Y, Yao PJ, Fu WM, Mattson MP, Itoyama Y, Onodera H, D'Souza I, Poorkaj PH, Bird TD, Schellenberg GD: Alteration in calcium channel properties is responsible for the neurotoxic action of a familial frontotemporal dementia tau mutation. J. Neurochem. 87:427-436, 2003.

Giaccone G, Rossi G, Farina L, Marcon G, Di Fede G, Catania M, Morbin M, Sacco L, Bugiani O, Tagliavini F: Familial frontotemporal dementia associated with the novel MAPT mutation T427M. J. Neurol. 252:1543-1545, 2005.

Goedert M, Jakes R: Mutations causing neurodegenerative tauopathies. Biochim. Biophys. Acta 1739:240-250, 2005.

Goedert M, Spillantini MG, Potier MC, Ulrich J, Crowther RA: Cloning and sequencing of the cDNA encoding an isoform of microtubuleassociated protein tau containing four tandem repeats differential expression of tau protein mRNAs in human brain. EMBO J. 8:393-399, 1989.

Gong CX, Grundke-Iqbal I, Iqbal K: Dephosphorylation of Alzheimer's disease abnormally phosphorylated tau by protein phosphatase-2A. Neuroscience 61:765-772, 1994a.

Gong CX, Grundke-Iqbal I, Damuni Z, Iqbal K: Dephosphorylation of microtubule-associated protein tau by protein phosphatase-1 and -2C and its implication in Alzheimer disease. FEBS Lett. 341:94-98, 1994b.

Gong CX, Liu F, Grundke-Iqbal I, Iqbal K: Posttranslational modifications of tau protein in Alzheimer's disease. J. Neural. Transm. 112:813-838, 2005.

Gotz J, Chen F, van Dorpe J, Nitsch RM: Formation of neurofibrillary tangles in P3011 tau transgenic mice induced by Abeta 42 fibrils. Science 293:1491-1495, 2001

Gotz J, Ittner LM, Schonrock N: Alzheimer's disease and frontotemporal dementia: prospects of a tailored therapy? Med. J. Aust. 185:381-384, 2006

Grover A, DeTure M, Yen SH, Hutton M: Effects on splicing and protein function of three mutations in codon $\mathrm{N} 296$ of tau in vitro. Neurosci Lett. 323:33-36, 2002.

Haass C, De Strooper B: The presenilins in Alzheimer's disease-proteolysis holds the key. Science 286:916-919, 1999

Halliday GM, Song YJ, Lepar G, Brooks WS, Kwok JB, Kersaitis C, Gregory G, Shepherd CE, Rahimi F, Schofield PR, Kril JJ: Pick bodies in a family with presenilin-1 Alzheimer's disease. Ann. Neurol. 57:139-143, 2005.

Hardy J, Selkoe DJ: Medicine - The amyloid hypothesis of Alzheimer's disease: progress and problems on the road to therapeutics. Science 297:353-356, 2002

Hayashi S, Toyoshima Y, Hasegawa M, Umeda Y, Wakabayashi K, Tokiguchi S, Iwatsubo T, Takahashi H: Late-onset frontotemporal dementia with a novel exon 1 (Arg5His) tau gene mutation. Ann. Neurol. 51:525-530, 2002.

Henderson JM, Carpenter K, Cartwright H, Halliday GM: Loss of thalamic intralaminar nuclei in progressive supranuclear palsy and Parkinson's disease: clinical and therapeutic implications. Brain 123:1410-1421, 2000.

Higuchi $M$, Ishihara $\mathrm{T}$, Zhang $\mathrm{B}$, Hong $\mathrm{M}$, Andreadis A, Trojanowski JQ, Lee VMY: Transgenic mouse model of tauopathies with glial pathology and nervous system degeneration. Neuron 35:433-446, 2002.

Hogg M, Grujic ZM, Baker M, Demirci S, Guillozet AL, Sweet AP, Herzog LL, Weintraub S, Mesulam MM, LaPointe NE, Gamblin TC, Berry RW et al.: The L266V tau mutation is associated with frontotemporal dementia and Pick-like 3R and 4R tauopathy. Acta Neuropathol. 106:323-336, 2003. 
Houlden H, Baker M, Morris HR, MacDonald N, Pickering-Brown S, Adamson J, Lees AJ, Rossor MN, Quinn NP, Kertesz A, Khan MN, Hardy $\mathbf{J}$ et al.: Corticobasal degeneration and progressive supranuclear palsy share common tau haplotype. Neurology 56: 1702-1706, 2001.

Hutton M, Lendon CL, Rizzu P, Baker M, Froelich $\mathrm{S}$, Houlden $\mathrm{H}$, Pickering-Brown $\mathrm{S}$, Chakraverty S, Isaacs A, Grover A, Hackett J, Adamson $\mathrm{J}$ et al.: Association of missense and 5'-splice-site mutations in tau with the inherited dementia FTDP-17. Nature.393:702705, 1998.

Karenberg A: A long story starting with a short paper: Early history of Pick's disease. Fortschr. Neurol. Psychiatr. 69:545-550, 2001.

Lewis J, McGowan E, Rockwood J, Melrose H, Nacharaju P, Van Slegtenhorst M, GwinnHardy K, Murphy MP, Baker M, Yu X, Duff $\mathrm{K}$, Hardy $\mathrm{J}$ et al.: Neurofibrillary tangles, amyotrophy and progressive motor disturbance in mice expressing mutant $(\mathrm{P} 301 \mathrm{~L})$ tau protein. Nat. Genet. 25:402-405, 2000.

Lewis J, Dickson DW, Lin WL, Chisholm L, Corral A, Jones G, Yen SH, Sahara N, Skipper L, Yager D, Eckman C, Hardy $\mathrm{J}$ et al.: Enhanced neurofibrillary degeneration in transgeni mice expressing mutant tau and APP. Science 293:1487-1491, 2001.

Lindwall G, Cole RD: Phosphorylation affects the ability of tau-protein to promote microtubule assembly. J. Biol. Chem. 259:5301-5305, 1984.

Lippa CF, Zhukareva V, Kawarai T, Uryu K, Shafiq M, Nee LE, Grafman J, Liang Y, St George-Hyslop PH, Trojanowski JQ, Lee VMY: Frontotemporal dementia with novel tau pathology and a Glu342Val tau mutation. Ann. Neurol. 48:850-858, 2000.

Litvan I, Hutton M: Clinical and genetic aspects of progressive supranuclear palsy. J. Geriatr. Psychiatry Neurol. 11: 107-114, 1998.

Mack TG, Dayanandan R, Van Slegtenhorst M, Whone A, Hutton M, Lovestone S, Anderton BH: Tau proteins with frontotemporal dementia-17 mutations have both altered expression levels and phosphorylation profiles in differentiated neuroblastoma cells. Neuroscience 108:701-712, 2001.

Mailliot C, Bussiere T, Hamdane M, Sergeant N, Caillet ML, Delacourte A, Buee L: Pathological tau phenotypes. The weight of mutations, polymorphisms, and differential neuronal vulnerabilities. Ann. N. Y. Acad Sci. 920:107-114, 2000.

Moller HJ, Graeber MB: The case described by Alois Alzheimer in 1911. Historical and conceptual perspectives based on the clinical record and neurohistological sections. Eur.
Arch. Psychiatry Clin. Neurosci. 248:111-122, 1998.

Mori H: Frontotemporal dementia and frontotemporal degeneration - how to define? (In Japanese). Rinsho Shinkeigaku 44:872874, 2004.

Morris HR, Gibb G, Katzenschlager R, Wood NW, Hanger DP, Strand C, Lashley T, Daniel SE, Lees AJ, Anderton BH, Revesz T: Pathological, clinical and genetic heterogeneity in progressive supranuclear palsy. Brain 125:969-975, 2002.

Morris HR, Osaki Y, Holton J, Lees AJ, Wood NW, Revesz T, Quinn N: Tau exon $10+16$ mutation FTDP-17 presenting clinically as sporadic young onset PSP. Neurology 61:102104, 2003.

Murrell JR, Spillantini MG, Zolo P, Guazzelli M, Smith MJ, Hasegawa M, Redi F, Crowther RA, Pietrini P, Ghetti B, Goedert M: Tau gene mutation G389R causes a tauopathy with abundant pick body-like inclusions and axonal deposits. J. Neuropathol. Exp. Neurol. 58: 1207-1226, 1999.

Neumann M, Schulz-Schaeffer W, Crowther RA, Smith MJ, Spillantini MG, Goedert M, Kretzschmar HA: Pick's disease associated with the novel Tau gene mutation K369I. Ann. Neurol. 50:503-513, 2001.

Nicholl DJ, Greenstone MA, Clarke CE, Rizzu P, Crooks D, Crowe A, Trojanowski JQ, Lee VMY, Heutink P: An English kindred with a novel recessive tauopathy and respiratory failure. Ann. Neurol. 54:682-686, 2003.

Oddo S, Caccamo A, Kitazawa M, Tseng BP, LaFerla FM: Amyloid deposition precedes tangle formation in a triple transgenic model of Alzheimer's disease. Neurobiol. Aging 24:1063-1070, 2003.

Oddo S, Billings L, Kesslak JP, Cribbs DH, LaFerla FM: Abeta immunotherapy leads to clearance of early, but not late, hyperphosphorylated tau aggregates via the proteasome. Neuron 43:321-332, 2004.

Papasozomenos SC, Binder LI: Phosphorylation determines 2 distinct species of Tau in the central-nervous-system. Cell Motil, Cytoskeleton 8:210-226, 1987.

Paudel HK, Lew J, Ali Z, Wang JH: Brain prolinedirected protein kinase phosphorylates tau on sites that are abnormally phosphorylated in tau associated with Alzheimer's paired helical filaments. J. Biol. Chem. 268:23512-23518, 1993.

Pei JJ, Braak E, Braak H, Grundke-Iqbal I., Iqbal K, Winblad B, Cowburn RF: Localization of active forms of C-jun kinase (JNK) and p38 kinase in Alzheimer's disease brains at different stages of neurofibrillary degeneration. J. Alzheimers Dis. 3:41-48, 2001. 
Pickering-Brown S, Baker M, Yen SH, Liu WK, Hasegawa M, Cairns N, Lantos PL, Rossor M, Iwatsubo T, Davies Y, Allsop D, Furlong R et al.: Pick's disease is associated with mutations in the tau gene. Ann. Neurol. 48:859-867, 2000.

Pickering-Brown SM, Baker M, Nonaka T, Ikeda K, Sharma S, Mackenzie J, Simpson SA, Moore JW, Snowden JS, de Silva R, Revesz T, Hasegawa $\mathrm{M}$ et al.: Frontotemporal dementia with Pick-type histology associated with Q336R mutation in the tau gene. Brain 127:1415-1426, 2004

Poorkaj P, Bird TD, Wijsman E, Nemens E, Garruto RM, Anderson L, Andreadis A, Wiederholt WC, Raskind M, Schellenberg GD: Tau is a candidate gene for chromosome 17 frontotemporal dementia. Ann. Neurol. 43:815-825, 1998.

Poorkaj P, Muma NA, Zhukareva V, Cochran EJ, Shannon KM, Hurtig H, Koller WC, Bird TD, Trojanowski JQ, Lee VMY, Schellenberg GD: An (R)5(L) tau mutation in a subject with a progressive supranuclear palsy phenotype. Ann. Neurol. 52:511-516, 2002.

Probst A, Tolnay M, Langui D, Goedert M, Spillantini MG: Pick's disease: hyperphosphorylated tau protein segregates to the somatoaxonal compartment. Acta Neuropathol. 92:588-596, 1996.

Puig B, Vinals F, Ferrer I: Active stress kinase p38 enhances and perpetuates abnormal tau phosphorylation and deposition in Pick's disease. Acta Neuropathol. 107:185-189, 2004.

Reynolds CH, Betts JC, Blackstock WP, Nebreda AR, Anderton BH: Phosphorylation sites on tau identified by nanoelectrospray mass spectrometry: differences in vitro between the mitogen-activated protein kinases ERK2, c-Jun N-terminal kinase and P38, and glycogen synthase kinase-3beta. J. Neurochem. 74:1587-1595, 2000.

Ridley RM, Baker HF, Windle CP, Cummings RM: Very long term studies of the seeding of betaamyloidosis in primates. J. Neural. Transm. 113:1243-1251, 2006.

Rizzini C, Goedert M, Hodges JR, Smith MJ, Jakes R, Hills R, Xuereb JH, Crowther RA, Spillantini MG: Tau gene mutation K257T causes a tauopathy similar to Pick's disease. J. Neuropathol. Exp. Neurol. 59:990-1001, 2000.

Ros R, Thobois S, Streichenberger N, Kopp N, Sanchez MP, Perez M, Hoenicha J, Avila J, Honnorat J, de Yebenes JG: A new mutation of the tau gene, G303V, in early-onset familial progressive supranuclear palsy. Arch. Neurol. 62:1444-1450, 2005a.

Ros R, Gomez Garre P, Hirano M, Tai YF, Ampuero I, Vidal L, Rojo A, Fontan A,
Vazquez A, Fanjul S, Hernandez J, Cantarero $S$ et al.: Genetic linkage of autosomal dominant progressive supranuclear palsy to 1q31.1. Ann. Neurol. 57:634-641, 2005b.

Rosso SM, van Herpen E, Deelen W, Kamphorst W, Severijnen LA, Willemsen R, Ravid R, Niermeijer MF, Dooijes D, Smith MJ, Goedert M, Heutink $\mathrm{P}$ et al.: A novel tau mutation, S320F, causes a tauopathy with inclusions similar to those in Pick's disease. Ann. Neurol. 51:373-376, 2002.

Santacruz K, Lewis J, Spires T, Paulson J, Kotilinek L, Ingelsson M, Guimaraes A, DeTure M, Ramsden M, McGowan E, Forster $C$, Yue $M$ et al.: Tau suppression in a neurodegenerative mouse model improves memory function. Science 309:476-481, 2005

Schwab C, DeMaggio AJ, Ghoshal N, Binder LI, Kuret J, McGeer PL: Casein kinase 1 delta is associated with pathological accumulation of tau in several neurodegenerative diseases. Neurobiol. Aging 21:503-510, 2000.

Sergeant N, Delacourte A, Buee L: Tau protein as a differential biomarker of tauopathies. Biochim. Biophys. Acta 1739:179-97, 2005

Shepherd CE, Gregory GC, Vickers JC, Brooks WS, Kwok JBJ, Schofield PR, Kril JJ, Halliday GM: Positional effects of presenilin-1 mutations on tau phosphorylation in cortical plaques. Neurobiol. Dis. 15:115-119, 2004.

Spillantini MG, Goedert M: Tau protein pathology in neurodegenerative diseases. Trends Neurosci. 21:428-433, 1998.

Stanford PM, Halliday GM, Brooks WS, Kwok JBJ, Storey CE, Creasey H, Morris JGL, Fulham MJ, Schofield PR: Progressive supranuclear palsy pathology caused by a novel silent mutation in exon 10 of the tau gene. Expansion of the disease phenotype caused by tau gene mutations. Brain 123:880893, 2000.

Steele JC, Richardson JC, Olszewski J: Progressive supranuclear palsy. A heterogeneous degeneration involving the brain stem, basal ganglia and cerebellum with vertical gaze and pseudobulbar palsy, nuchal dystonia and dementia. Arch. Neurol. 10:333-359, 1964.

Tanemura K, Murayama M, Akagi T, Hashikawa $\mathrm{T}$, Tominaga $\mathrm{T}$, Ichikawa $\mathrm{M}$, Yamaguchi $\mathrm{H}$, Takashima A: Neurodegeneration with tau accumulation in a transgenic mouse expressing V337M human tau. J. Neurosci. 22:133-141, 2002.

Tomizawa K, Omori A, Ohtake A, Sato K, Takahashi M: Tau-tubulin kinase phosphorylates tau at Ser-208 and Ser-210, sites found in paired helical filament-tau. FEBS Lett. 492:221-227, 2001. 
van Slegtenhorst M, Lewis J, Hutton M: The molecular genetics of the tauopathies. Exp. Gerontol. 35:461-471, 2000.

Weingarten MD, Lockwood AH, Hwo SY, Kirschner MW: A protein factor essential for microtubule assembly. Proc. Natl. Acad. Sci. U.S.A. 72:1858-1862, 1975.

Wilhelmus MM, Otte-Holler I, Davis J, Van Nostrand WE, de Waal RMW, Verbeek MM: Apolipoprotein E genotype regulates amyloidbeta cytotoxicity. J. Neurosci. 25:3621-3627, 2005.

Yen SH, Hutton M, DeTure M, Ko LW, Nacharaju P: Fibrillogenesis of tau: insights from tau missense mutations in FTDP-17. Brain Pathol. 9:695-705, 1999.

Yoshida H, Crowther RA, Goedert M: Functional effects of tau gene mutations Delta N296 and N296H. J. Neurochem. 80:548-551, 2002.
Zarranz JJ, Ferrer I, Lezcano E, Forcadas MI, Eizaguirre B, Atares B, Puig B, GomezEsteban JC, Fernandez-Maiztegui C, Rouco I, Perez-Concha T, Fernandez M et al.: A novel mutation $(\mathrm{K} 317 \mathrm{M})$ in the MAPT gene causes FTDP and motor neuron disease. Neurology 64:1578-1585, 2005.

Zhukareva V, Mann D, Pickering-Brown S, Uryu K, Shuck T, Shah K, Grossman M, Miller BL, Hulette CM, Feinstein SC, Trojanowski JQ, Lee VMY: Sporadic Pick's disease: a tauopathy characterized by a spectrum of pathological tau isoforms in gray and white matter. Ann. Neurol. 51:730-739, 2002. 